\title{
The effect of chemically enhanced oil recovery on thin oil rim reservoirs
}

\author{
O. A. Olabode ${ }^{1}$ (i) V. O. Ogbebor ${ }^{1} \cdot$ E. O. Onyeka ${ }^{1} \cdot$ B. C. Felix ${ }^{1}$
}

Received: 19 September 2020 / Accepted: 7 January 2021 / Published online: 18 February 2021

(c) The Author(s) 2021

\begin{abstract}
Oil rim reservoirs are characterised with a small thickness relative to their overlying gas caps and underlying aquifers and the development these reservoirs are planned very carefully in order to avoid gas and water coning and maximise oil production. Studies have shown low oil recoveries from water and gas injection, and while foam and water alternating gas injections resulted in positive recoveries, it is viewed that an option of an application of chemical enhanced oil recovery option would be preferable. This paper focuses on the application of chemical enhanced oil recovery to improve production from an oil rim reservoir in Niger Delta. Using Eclipse black oil simulator, the effects of surfactant concentration and injection time and surfactant alternating gas are studied on overall oil recovery. Surfactant injections at start and middle of production resulted in a 3.7 MMstb and 3.6 MMstb at surfactant concentration of $1 \%$ vol, respectively. This amounted to a $6.6 \%$ and $6.5 \%$ increment over the base case of no injection. A case study of surfactant alternating gas at the middle of production gave an oil recovery estimate of $10.7 \%$.
\end{abstract}

Keywords Oil rims $\cdot$ Chemical enhanced oil recovery $\cdot$ Surfactants $\cdot$ And concurrent production

$\begin{array}{ll}\text { Abbreviations } \\ \text { FWCT } & \text { Field water cut } \\ \text { FOE } & \text { Field oil efficiency } \\ \text { FOPT } & \text { Field oil production total } \\ \text { EOR } & \text { Enhanced oil recovery } \\ \text { CEOR } & \text { Chemical enhanced oil recovery } \\ \text { FOPR } & \text { Field oil production rate }\end{array}$

\section{Introduction}

Oil rim reservoirs are reservoirs with a generally low thickness compared to thickness of the gas column above it and aquifer below it. Robert and Jacques (1953) described an oil

O. A. Olabode

Oluwasanmi.olabode@covenantuniversity.edu.ng

V. O. Ogbebor

osabouhien.ogbebor@gmail.com

E. O. Onyeka

ella.onyeka6@gmail.com

B. C. Felix

belemafelix13@gmail.com

1 Department of Petroleum Engineering, Covenant University, Ota, Ogun State, Nigeria rim reservoir as one whose major drive mechanism is gas cap drive and has solution drive as a minor drive mechanism. An aquifer may be present, but its effect is usually not as pronounced as that of gas cap and solution drive mechanism. Oil rims have been classified into different categories including the ultrathin oil rim with oil reservoir thickness below $30 \mathrm{ft}$ as described by Nagib et al. (2011), Vo et al. (2001), a pancake oil rim with reservoir thickness of 20-50ft Sulaiman and Bretherton (1989) and thin oil rims of 50-100 ft Samsunder et al. (2005). These reservoirs are located around the world and require careful planning and execution in order to optimise hydrocarbon production from them due to their low thickness. Various studies have been carried out on optimization of production parameters for oil rim reservoirs. Olabode et al. (2018a) observed that it is best to maintain and optimize reservoir and production parameters before carrying out recovery options on oil rim reservoirs. Their study suggests that a horizontal well at a rate of between 1000 and $1500 \mathrm{stb} /$ day is optimum for oil recovery. These optimizations will help in proper production forecast for oil rim reservoirs (Olabode et al. 2018b). Olabode et al. (2020a) also emphasized the need for proper well placement with respect to fluid contacts as an essential factor for optimum oil and gas productivity. Olabode (2020b) concluded that for optimum oil recovery during secondary injection schemes, it is best to place the water injector 
at an up dip location of the reservoir. The use of enhanced oil recovery (EOR) techniques has also been investigated for oil rim reservoir development. Olabode et al. (2018c) studied the effect of foam and WAG (water alternating gas) injection on performance of thin oil reservoirs, showing that foam up dip and foam down dip gave increased oil recoveries of $8.57 \%$ and $8.56 \%$, higher than $8.35 \%$ and $7.94 \%$ from WAG up dip and Wag down dip injections, respectively. Maroua and Mohsen (2019) did a simulation study on the impact of water flooding, immiscible gas injection and surfactant flooding on oil rim reservoir development; results from this study showed that surfactant flooding gave a higher displacement efficiency in comparison with water flooding and its application in reducing residual oil saturation could give a higher ultimate oil recovery. In this paper, the impact of water injection will be compared with surfactant injection at different concentrations on oil recovery from an oil rim reservoir in the Niger Delta basin.

Surfactants are added in small amounts of injection water to reduce the interfacial tension between oil and brine, helping to mobilise residual oil left behind during secondary recovery. Surfactants are also capable of altering the wettability of rocks by increasing the imbibition of water to the rocks, (Dieshad et al. 2009). However, the alteration of wettability by surfactants is more pronounced in carbonate formations as carbonate rocks are usually oil wet, (Sheng 2013). They can function as wetting agents, detergents, emulsifiers, dispersants and foaming agents. A surfactant molecule consists of a non-polar hydrophobic (lipophilic) tail and a polar hydrophilic (lipophobic) head.

The hydrophobic tail has a higher affinity for oil, while the hydrophilic head has a greater affinity for water (Fig. 1). This structure makes surfactants soluble in both the water and oil phases. When the surfactants are injected into the oil phase, it causes a disruption in the original oil structure because of the hydrophilic group and increases the free energy in the system, the system tries to adjust for the presence of this surfactant by reducing contact with the

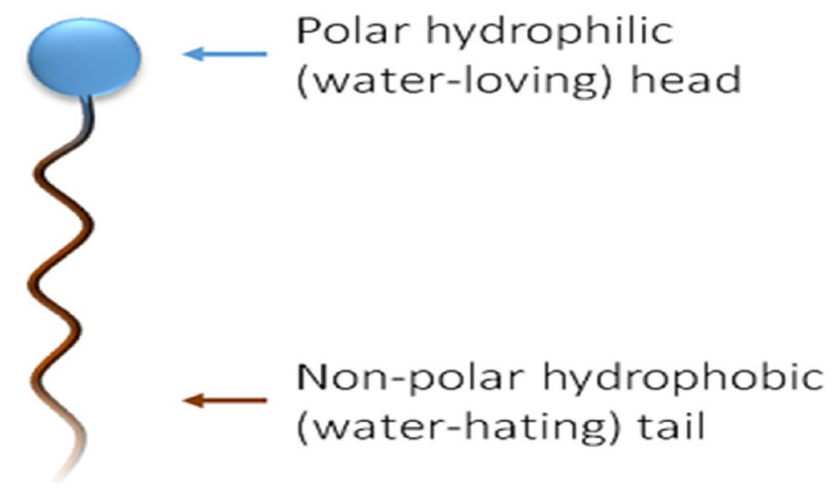

Fig. 1 General structure of a surfactant molecule. Source University of Bistol hydrophiles. Likewise, when the surfactant is injected into the water phase, it causes a disruption in the original water structure due to the hydrophobic portion of the molecule and the system will also try to adjust for the presence of the hydrophobes by reducing contact with the hydrophobes. These adjustments cause the surfactant molecules to be absorbed at the interface of the two fluids causing a reduction in the interfacial tension, (Rosen and Kunjappu 2012). The surfactants accumulate at the interface in the form of micelles, Keshtkar et al. (2015)

Pope (2007) outlines the following four classes of surfactants:

- Anionic surfactants

- Cationic surfactants

- Non-ionic surfactants

- Z witter-ionic surfactants

According to Sheng (2015), anionic surfactants are preferred for the following reasons:

- Low adsorption tendency on sandstones and carbonates

- Can be modified to fit different scenarios

- Inexpensive in special cases

- Sulphates can be applied to low temperature reservoirs

However, cationic surfactants can be applied as co-surfactants. Generally, non-ionic surfactants have not provided satisfactory results for EOR.

The success of a surfactant flooding process is a function of the type of reservoir rock, i.e. sandstone or carbonate. Most surfactant flooding treatments have been carried out on sandstone reservoirs because of its favourable characteristics. In this project, the effect of the concentration and injection rate of surfactant employed in surfactant flooding will be analysed in a numerical simulation study.

\section{Surfactant flooding}

Surfactant flooding is one of the chemical EOR schemes. Surfactant flooding is carried out to recover oil that is trapped by capillary forces after secondary recovery has taken place. The mechanism behind this is to reduce the interfacial tension (IFT) between the oil and water in the pore spaces. When designed properly, a surfactant flooding scheme can reduce IFT by about $10^{-3}$ dynes $/ \mathrm{cm}$. It aids to recover an additional $60 \%$ of original oil in place left behind in the reservoir after waterflooding.

\section{Mechanisms of surfactant flooding}

Surfactants mobilise trapped oil through two major trapping mechanisms which include reduction of interfacial tension 
and wettability alteration. There is also a third and less common mechanism that is known as swelling.

\section{Reduction of interfacial tension (IFT)}

In order to describe this mechanism, the concept of capillary number and its relationship with residual oil saturation must be introduced first. The capillary number is the ratio of viscous forces to capillary forces. In its simplest form, it is given by the following equation:

$N_{c}=\frac{U \mu}{\sigma(\cos \theta)}$

where.

$N_{c}$ is the capillary number.

$U$ is the displacing Darcy velocity.

$\mu$ is the viscosity of the displacing fluid.

$\theta$ is the contact angle.

$\sigma$ is the interfacial tension between the displacing fluid and the displaced fluid.

\section{Oil swelling}

This mechanism involves the formation of micro-emulsions after the injection of the surfactant, (Perm Inc). Relevant micro-emulsions under this mechanism include the type II micro-emulsion in which water is solubilised in the residual oil forming an upper emulsion phase, and the type III microemulsion in which both water and oil solubilise in each other and form middle emulsion phase. The solubilisation of water in oil causes the oil to swell; hence, its volume increases, thereby increasing its relative permeability and easing its production.

\section{Volumetric sweep efficiency}

Volumetric sweep efficiency quantifies the three-dimensional effects of reservoir heterogeneities, Chauhan (2014). It is given as the product of the areal sweep efficiency and vertical sweep efficiency.

$E_{V}=E_{\mathrm{A}} * E_{I}=\left(\frac{A_{\mathrm{d}}}{A_{\mathrm{R}}}\right) * h * \Phi * S \ldots$

where

$E_{\mathrm{A}}$ is the areal sweep efficiency.

$A_{\mathrm{d}}$ is the area of displacement.

$A_{\mathrm{R}}$ is the area of the reservoir.

$\Phi$ is the porosity.

$S$ is hydrocarbon saturation.
In surfactant flooding schemes, in order to maintain a good volumetric sweep efficiency, the mobility ratio must be kept lower than one to preventing viscous fingering from occurring. The surfactant slug that is injected should have a low mobility in order for it to move through low permeability zones and other parts of the reservoir that are not in close proximity to the injection well, thus improving volumetric efficiency.

\section{Screening criteria}

Surfactant screening is carried out in order to evaluate the performance a single surfactant or a combination of different surfactants under different reservoir conditions in order to ascertain suitability for a particular flooding scheme, Hirasaki et al. (2008). The following parameters were outlined by Sheng (2015) as the important factors that affect the choice of surfactants:

- The type of formation, salinity of formation water and presence of divalent ions

- The depth and temperature of the reservoir

- Permeability of the formation

- Crude oil composition, API gravity and viscosity

- Residual oil saturation

- Storage capacity

According to NPC (1976), commercial availability, type of surfactants and economic conditions must all be put into consideration during screening activities.

In his paper, Sheng (2015) provided a summary of technical screening criteria proposed by various scholars in Table 1:

\section{Niger delta case study}

The Niger Delta region of Nigeria holds a vast amount of hydrocarbon resources. The reservoirs found in this region are located in anticlinal and synclinal structures. The reservoirs are Early Miocene in age and record successive periods of outbuilding and early destruction of Niger Delta Fig. 2 is a particular field in the Niger Delta region which hold massive reserves of oil in its oil rim reservoirs. Gas, oil and water positions and volumes are each represented by green, red and blue colours, respectively.

Figure 2 shows the case study reservoir $\mathrm{C} 2$ field description with stacked oil rim reservoir layers. 


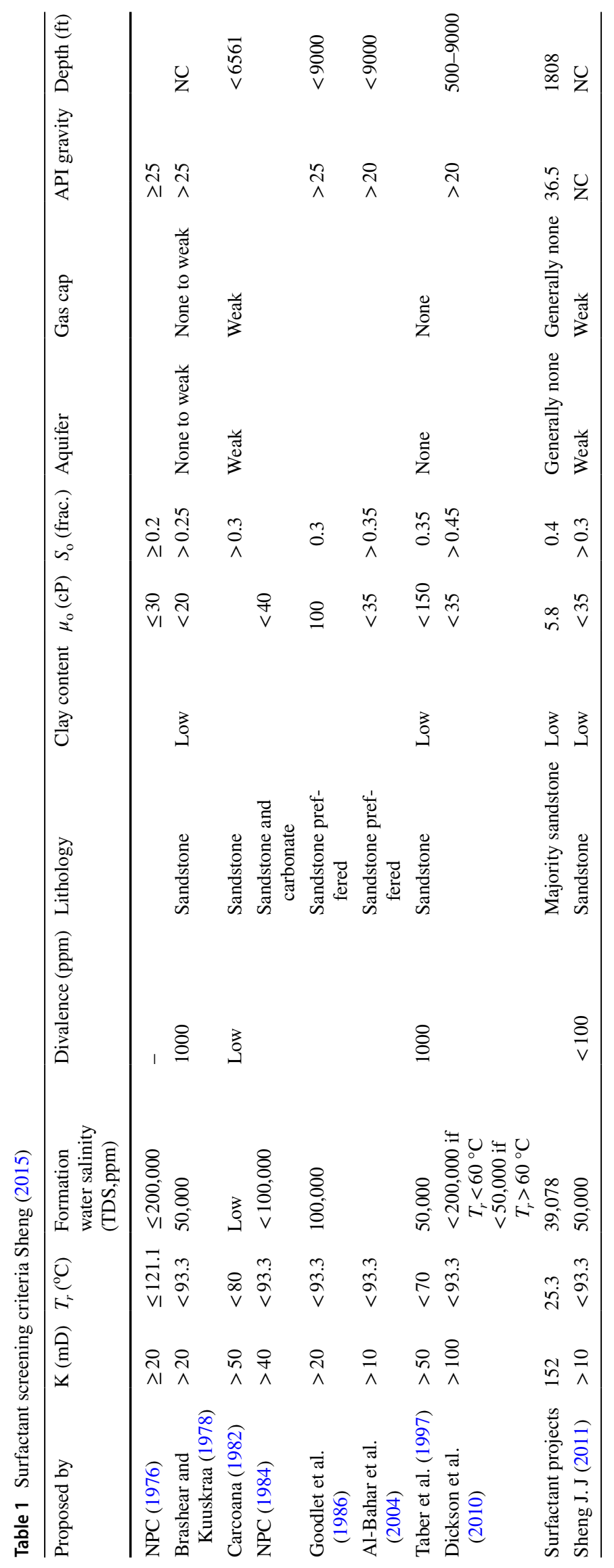




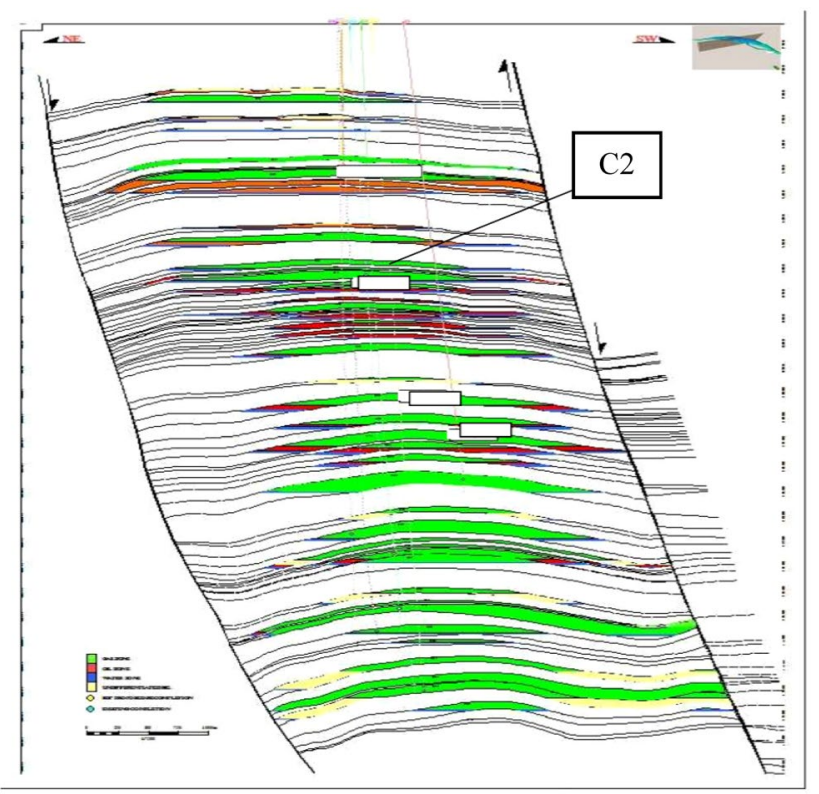

Fig. 2 Field description of C2 reservoir. Source The Shell Petroleum Development Company, Port Harcourt

\section{Methodology}

\section{C2 model grid description}

The oil rim reservoir C2 is used to verify the effect chemically enhanced oil recovery options on oil recovery. The Petrel software is used to discretize the subsurface map in Fig. 3 for easy upload into the grid section of Eclipse software (Fig. 4). The GridSim Module was used to build the reservoir grid model. The reservoir lies between 10,000 and 10,450 feet. The Cartesian grid is set into $75 \times 50 \times 20$ grid cells with 74,000 cells set active by boundary definition and shaped according to the cross sections drawn across the reservoir sand map in both $\mathrm{X}$ and $\mathrm{Y}$ directions. There are 32,420 active cells and 41,580 inactive cells. The grid section is used to assign petro-physical properties and their values as described in Table 2. To initialise the active grid cells, the solution and PVT properties are incorporated and constructed by making use of black oil properties in the manual. The surfactant model in the Eclipse software is activated with all the necessary keywords and parameters as contained in the manual.

The reservoir has been history matched via 5 initial wells that were in production since 1968 and have reached peak water cuts and gas oil ratios after over 30 years of production (Fig. 4). This prompted the initialisation of 8 more wells (serving as base case at 2010) in locations of high oil saturation in the reservoir (Fig. 5). The simulation period for this prediction is between 2010 and 2046. To determine the performance of the reservoir drives, $\mathrm{M}$-Bal is used to generate energy plots from reservoir properties in Table 2. Thus, Figs. 5 and 6 show the relative contribution different reservoir drives and that the reservoir is actively under aquifer drive with the gas cap the minor drive.

\section{Simulation cases}

To verify the oil recovery from different scenarios of chemically enhanced oil recovery, a base case has to be recognised.
Fig. 3 Sub surface geological map of $\mathrm{C} 2$

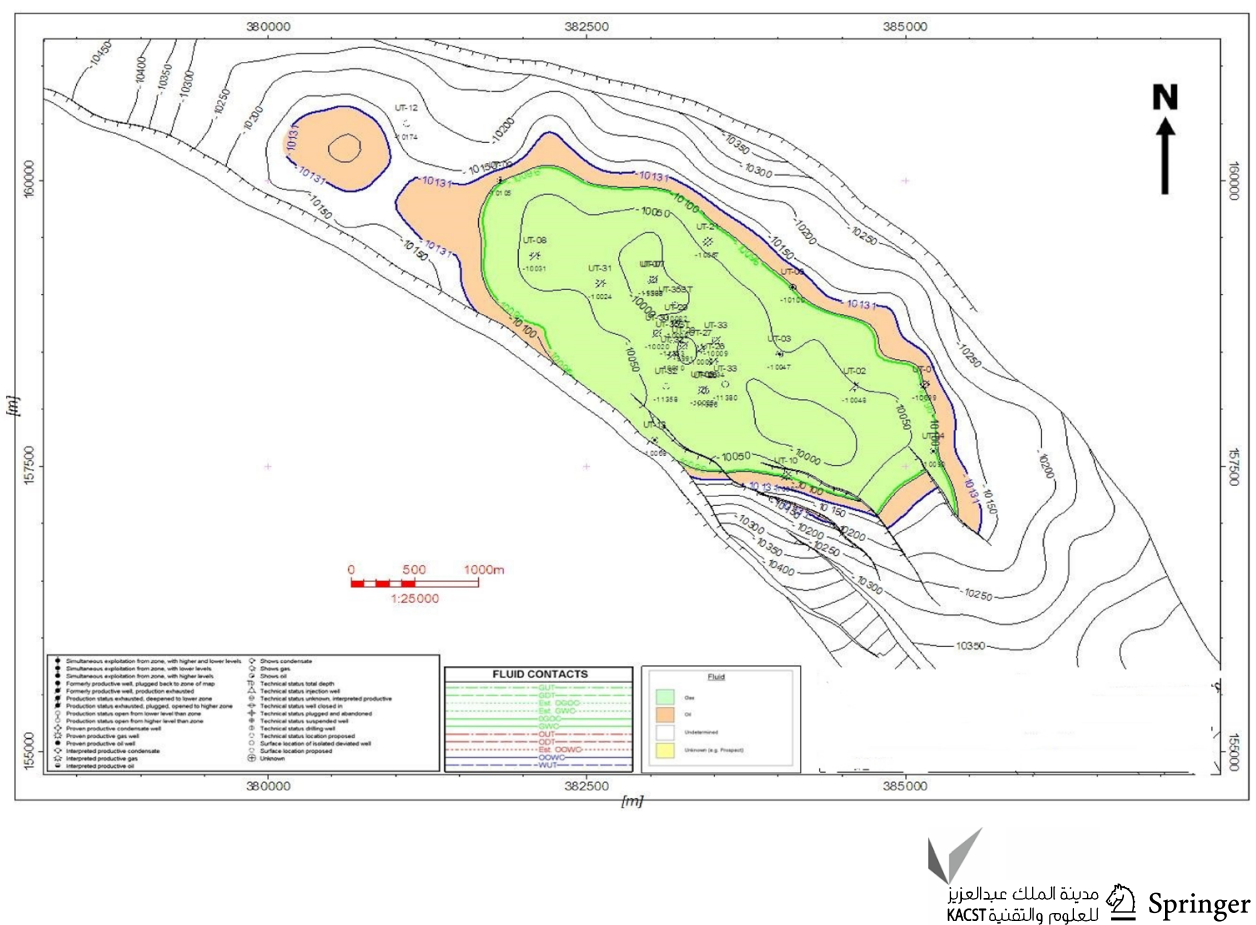


Fig. 4 Floviz model of $\mathrm{C} 2$ reservoir before the start of simulation

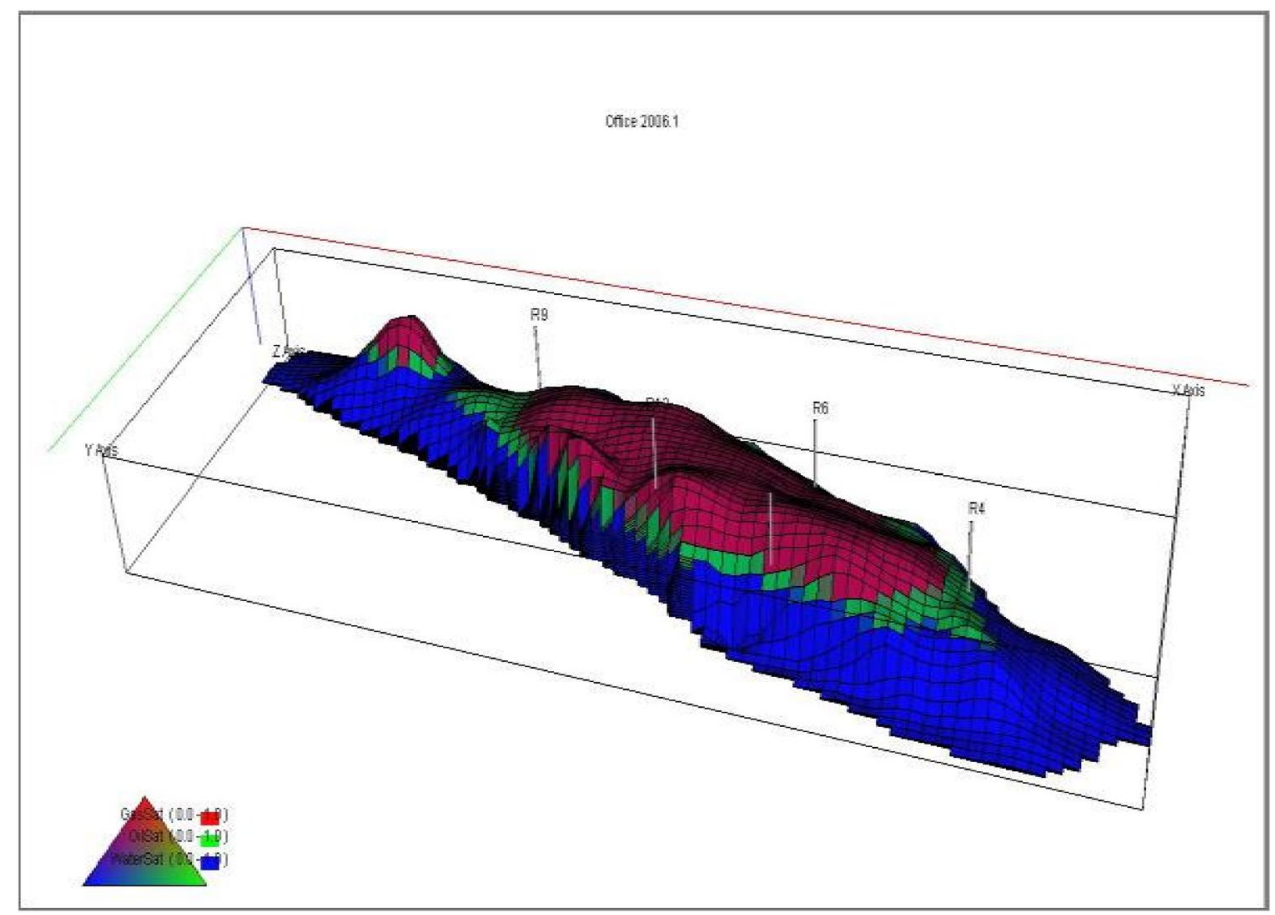

Table 2 Properties of $\mathrm{C} 2$ reservoir

\begin{tabular}{llll}
\hline Properties & Value & Properties & Value \\
\hline Oil sand porosity & 0.26 & Oil rim thickness (ft) & 38 \\
Gas sand porosity & 0.24 & Swc & 0.14 \\
Sh oil & 0.9 & Oil viscosity (cP) & 0.43 \\
Sh gas & 0.77 & Oil gravity (API) & 32 \\
NTG & 0.8 & Boi (bbl/STB) & 1.48 \\
Permeability (mD) & $400-1500$ & Rsi (SCF/STB) & 1035 \\
Sand thickness (ft) & 71 & Ti (f) & 179 \\
Pi (psi) & 4394 & Np (MMstb) & 10.73 \\
Pb (psi) & 4394 & Free gas in place (bcf) & 128.5 \\
STOIIP (MMbbls) & 35.9 & $\Delta P / P i ~ @ N p / N$ & $7 \% @ 26 \%$ \\
\hline
\end{tabular}

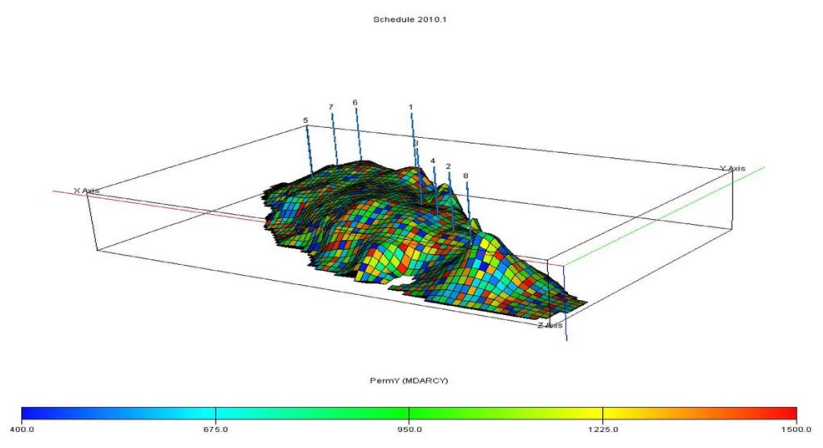

Fig. 5 Floviz model of C2 reservoir showing 8 initialised wells

Since the scope of this work is outside secondary injection, the base case will be a case scenario of no injection (initial 8 horizontal wells producing at an optimised rate of $100 \mathrm{stb} /$ day). Then, a case study of effect of varying surfactant concentration (via water injector well at an injection rate of
$2500 \mathrm{stb} /$ day) with respect to time and surfactant alternating gas is considered. Thus, the following case studies:

- No injection at all (at 2010)

- Injection at the start of production in December 2010

- Injection at the middle of production in November 2023

- Surfactant alternating gas. 
Fig. 6 C2 Campbell plot for C2 reservoir

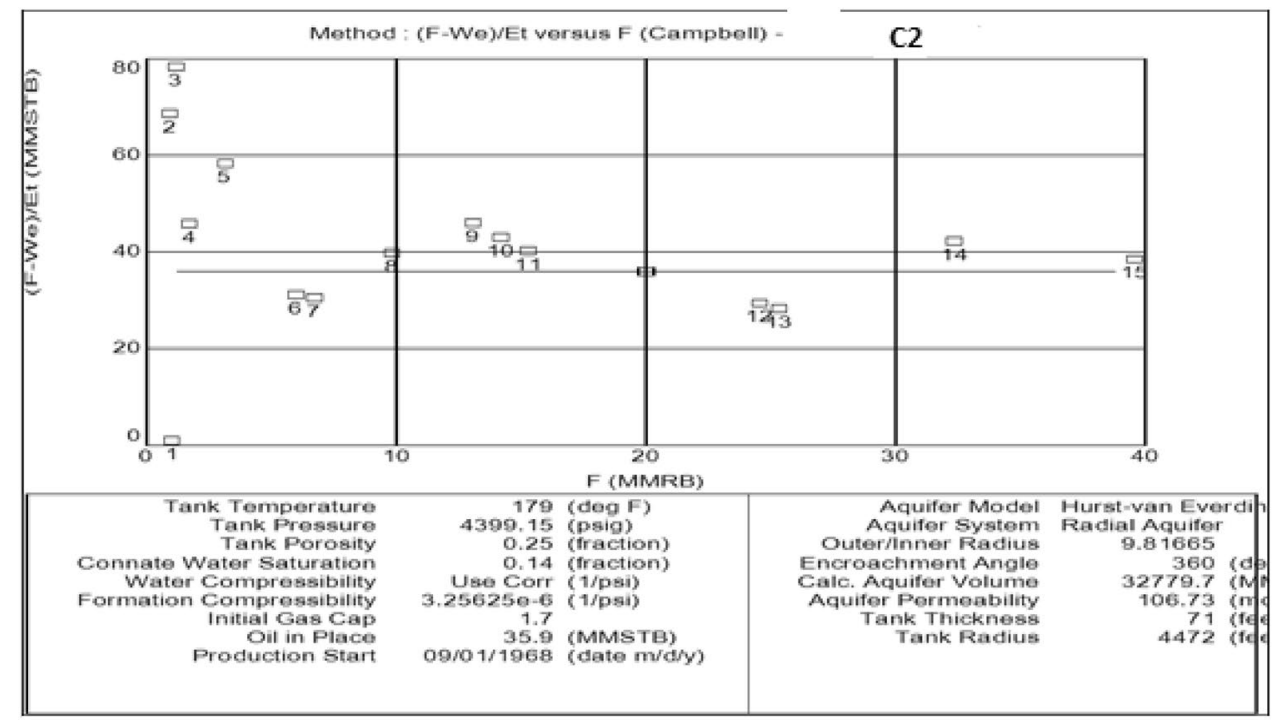

Table 3 Results summary for scenario 1

\begin{tabular}{ll}
\hline FOE at November 2010 & 0.093 \\
FOPT at November 2010 & $3,352,051.8 \mathrm{STB}$ \\
FOPR at November 2010 & $156.73386 \mathrm{STB} /$ day \\
FWCT at November 2010 & 0.9597106 \\
\hline
\end{tabular}

\section{Results and discussions}

\section{Scenario 1}

This case study depicts oil recovery profile from the 8 infill wells under normal reservoir conditions (no injection). The results show oil recovery as low as $0.09 \%$ and production of approximately 3.4 MMstb as described in Table 3. The production profile for this case study is described by Figs. 7a-d. There is a rapid drop in oil production rate as expected due to the absence of pressure support and the fact that the pressure had initially declined from start of production in 1968. It is also expected that the water cut will rise as the reservoir is under an active aquifer support as noted in the energy plots (Fig. 8).

\section{Scenario 2}

In this scenario, surfactant injection is modelled to start at onset of production (December 2010). Under this scenario, two cases were considered. The first case involved injection of only water (no surfactants), and the second case involved injection of surfactants of concentrations of $1 \mathrm{vol} \%, 5 \mathrm{vol} \%$, $15 \mathrm{vol} \%$ and $30 \mathrm{vol} \%$ of water injected. From the results (Table 4), it is seen that injection of a surfactant concentration of 1 vol\% gave the highest cumulative oil produced of 3.57 MMstb (Fig. 9a). The oil recovery and production total for surfactant concentrations 5 to $15 \mathrm{vol} \%$ are closely similar to those at $1 \%$ (Fig. $9 \mathrm{~b}$ and c). However, for the concentration of $30 \mathrm{vol} \%$, it produced a remarkably lower cumulative oil production of $3,282,718 \mathrm{STB}$. This can be attributed to a high level of surfactant retention. This high level of retention causes an increase in interfacial tension between the oil and the surfactant mixture, causing the oil to be trapped in the pore spaces. The results are summarised in the table:

\section{Scenario 3}

In this scenario, injection of fluids commenced at the middle of production in November 2023. Like scenario 2, two cases were considered. The first case involved injection of only water (no surfactants), and the second case involved injection of varying surfactants concentrations as a percentage of water injected (Table 5). The results indicate that surfactant concentrations increased oil recovery and the optimum oil recovery was at surfactant concentration of $1 \%$. The plots in Fig. 10 describe the plots from different surfactant 


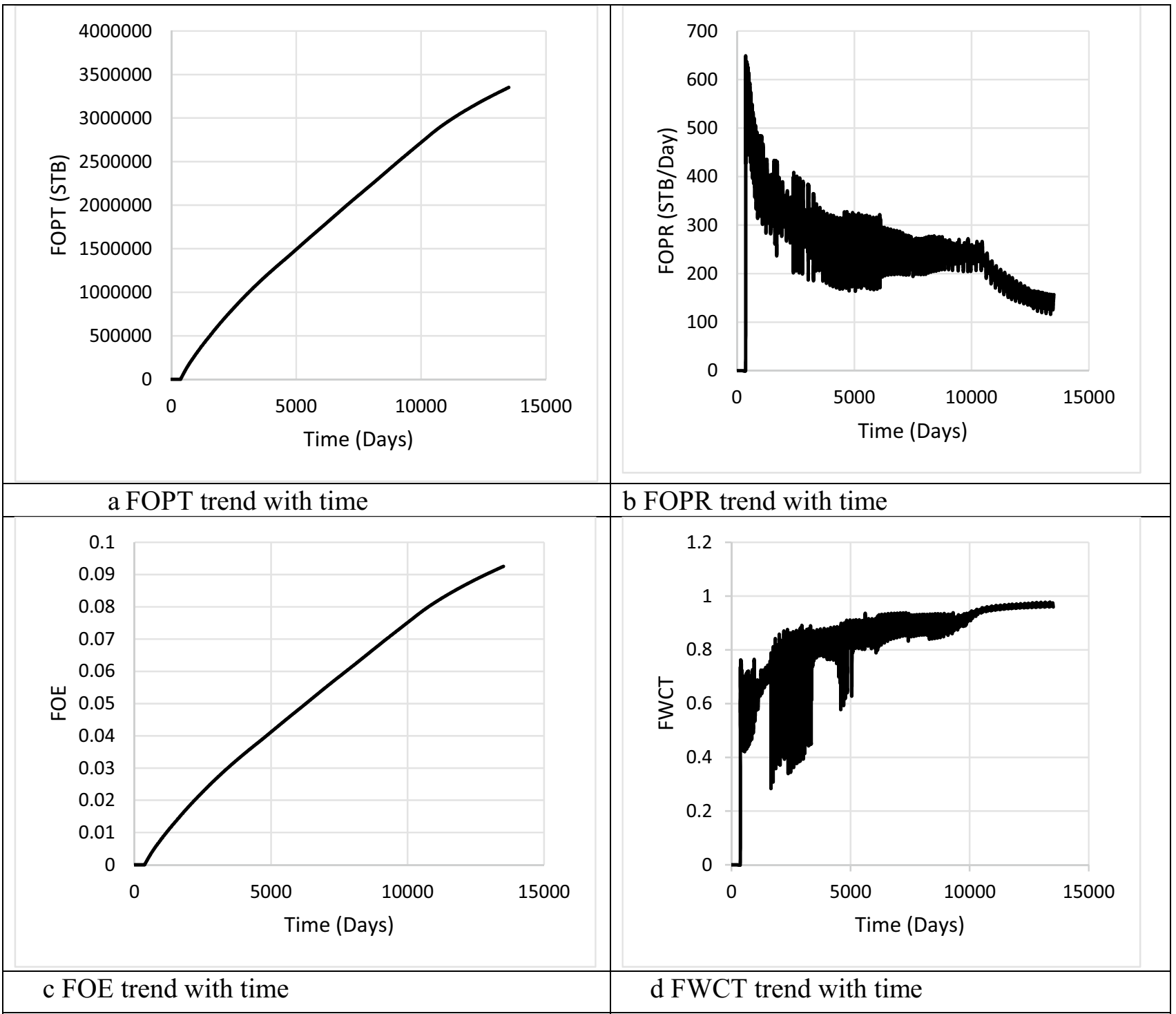

Fig. 7 a FOPT trend with time; b FOPR trend with time; c FOE trend with time; d FWCT trend with time

concentration. The plots show maximum and minimum oil recoveries at $1 \%$ and $30 \%$ surfactant concentration.

\section{Comparisons between scenarios 2 and 3}

The charts in Fig. 11a, b, c and d show that injecting at a surfactant concentration of $1 \% \mathrm{vol}$ is profitable for maximum oil recovery and this should be initiated at the onset of production.

\section{Scenario 4}

Scenario 4 involves the application of surfactant alternating gas (SAG) injection for the development of the oil rim reservoir. For this scenario, simulation was also carried out for two cases: injection at the start of production and injection at the middle of production. A surfactant concentration of 1 volume $\%$ was selected since it gave the highest recovery amongst the previous scenarios and from Fig. 12c, surfactant 
Fig. 8 AR2 energy plot AR2 reservoir

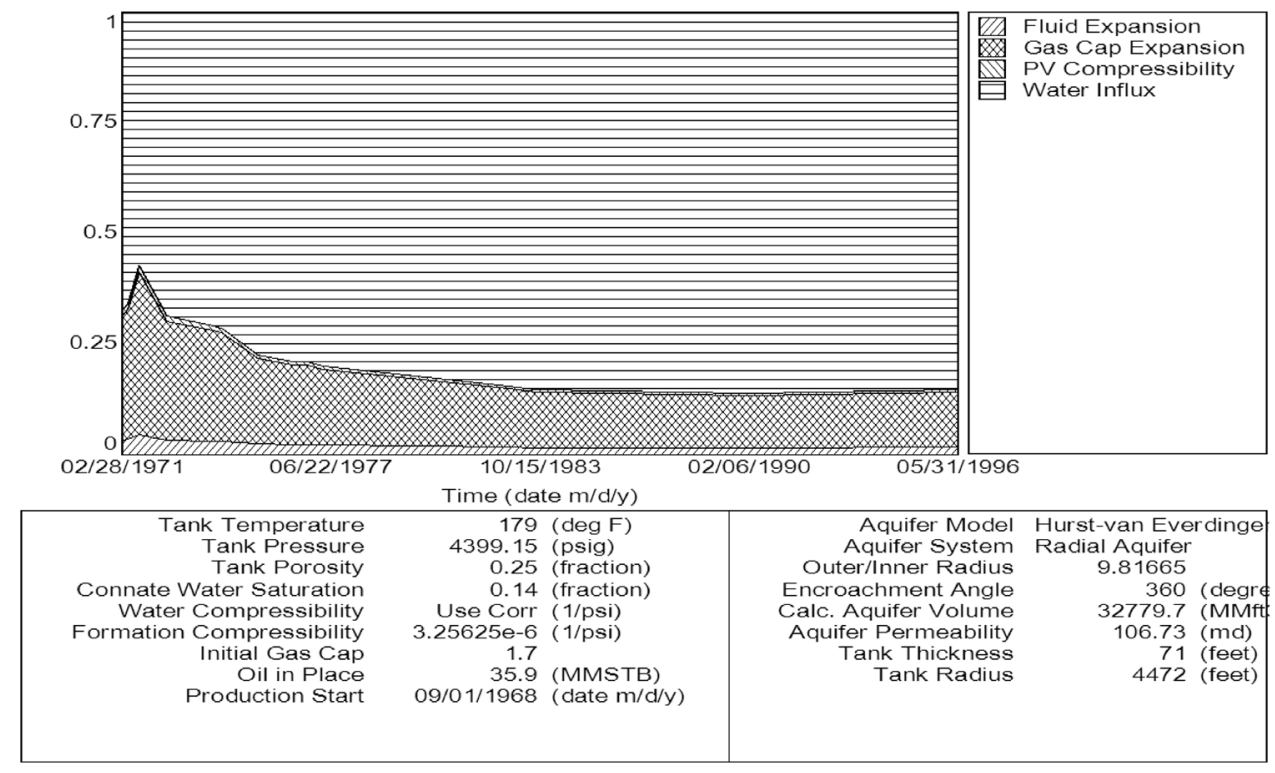

\begin{tabular}{lllll}
\hline Results at December 2010 & \multicolumn{3}{l}{} \\
\hline Surfactant Conc (vol\%) & (FOE) & (FOPT) (STB) & (FOPR) (STB/day) & (FWCT) \\
\hline 0 (water injection) & 0.096617751 & $3,499,010.5$ & 157.76485 & 0.96075308 \\
1 & 0.098634697 & $3,571,968.5$ & 211.14687 & 0.95357502 \\
5 & 0.097971737 & $3,548,131.8$ & 178.27037 & 0.95054859 \\
10 & 0.098197669 & $3,556,198$ & 150.6162 & 0.95584935 \\
15 & 0.097971737 & $3,548,131.8$ & 178.27037 & 0.95054859 \\
30 & 0.090643935 & $3,282,718$ & 220.88638 & 0.93922669 \\
\hline
\end{tabular}

Table 4 Results summary for scenario 2 of injection at the middle of production. The table shows the results of this scenario at the end of the simulation in November 2046:

The results from this scenario show that surfactant injection at middle of production will yield a higher recovery compared to the previous scenarios which suggests better recovery when surfactant is injected at onset.
This can be attributed to late gas breakthrough in the case injection at the middle of production and at $1 \%$ weight volume gave the recovery. An optimal rate of $250 \mathrm{Mscf} /$ day was used for gas injection. From the results, injection at the middle of production gave a higher recovery of 3,915,821 STB (Fig. 12a), about $2.5 \%$ higher than the recovery of 3,175,512 STB from injection at the beginning of production (Table 6). 




Fig. 9 a FOPT at December 2010; b FOPR at December 2010; c FOE at December 2010; d FWCT at December 2010

Table 5 Results summary for scenario 3

\begin{tabular}{lllll}
\hline Surfactant Conc & (FOE) & (FOPT) (STB) & (FOPR) (STB/day) & (FWCT) \\
\hline \multicolumn{2}{l}{ Results at November 2023} & & & \\
0 (water only) & 0.095301099 & $3,451,587.8$ & 177.06764 & 0.96842259 \\
1 & 0.09831766 & $3,560,780.3$ & 188.8085 & 0.96123546 \\
5 & 0.098226346 & $3,557,526$ & 136.8401 & 0.95724368 \\
10 & 0.098079242 & $3,552,244.8$ & 134.84355 & 0.9578014 \\
15 & 0.097887054 & $3,545,377.3$ & 186.62827 & 0.96139079 \\
30 & 0.093056202 & $3,369,926$ & 218.87389 & 0.94760925 \\
\hline
\end{tabular}




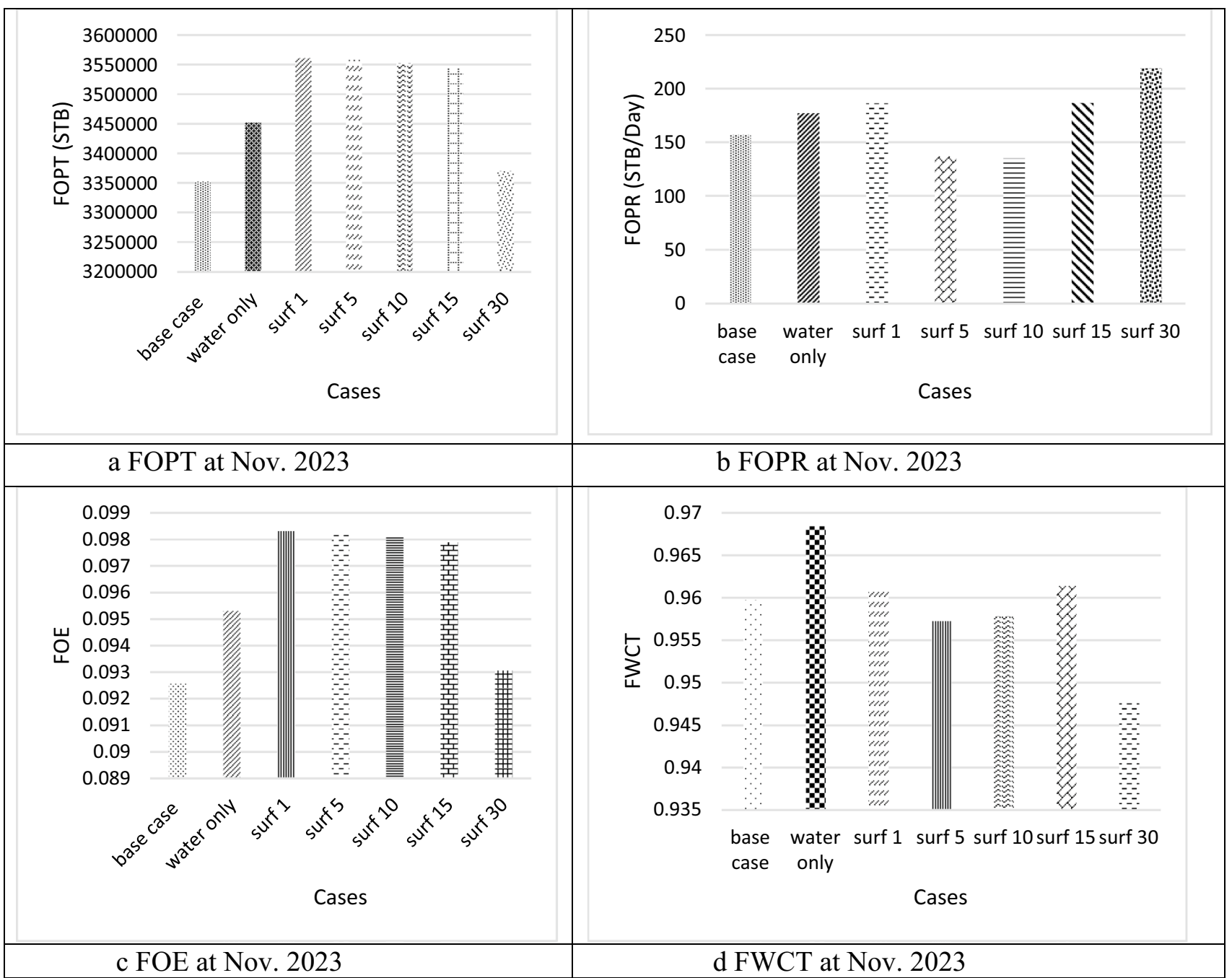

Fig. 10 a FOPT at November 2023; b FOPR at November 2023; c FOE at November 2023; d FWCT at November 2023

\section{Conclusion and recommendation}

Results show that surfactant injection either at onset or middle of production positively impacts oil recovery above water injection. For a reliable recovery, it is best to consider surfactant alternating injection at a concentration of $1 \%$ vol at the middle of production. Modifications can be made to the values of parameters used in the surfactant model based on laboratory data on different types of surfactant. If this is achieved, simulations can be carried out to determine the best surfactants for different reservoir conditions and give more accurate recovery predictions from these reservoirs. To further study the applications of chemicals in EOR projects oil rim reservoirs, the use of polymers (bio and nonbio) as investigated by Olabode et al. (2020c) and Olabode et al. (2020d) can be applied to investigate its suitability in improving oil recovery in oil rims with medium or heavy crude.

There are no ethical issues or conflict of interests surrounding the development of this study. The data for this study will be made available on request. 


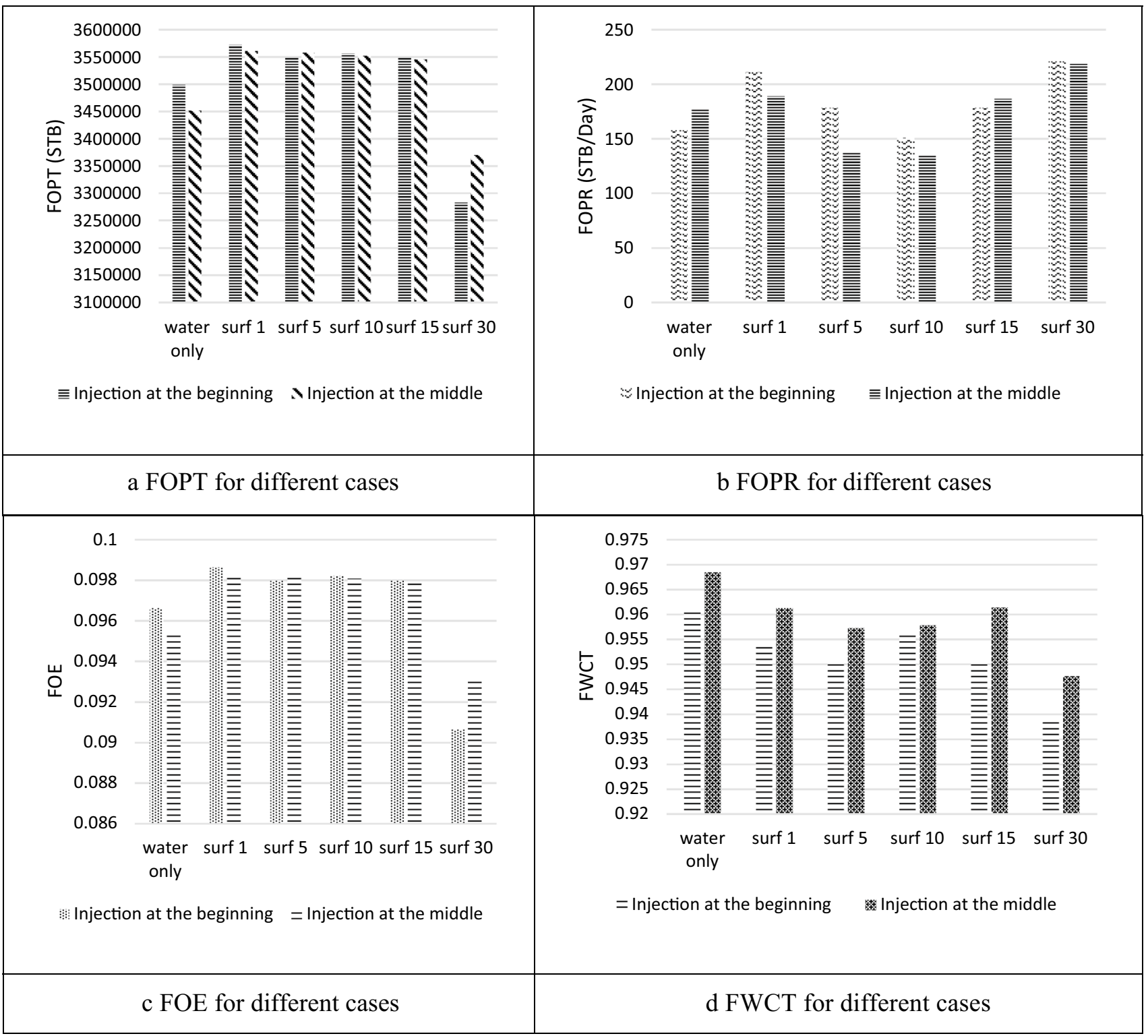

Fig. 11 a FOPT for different cases; b FOPR for different cases; $\mathbf{c}$ FOE for different cases; $\mathbf{d}$ FWCT for different cases 


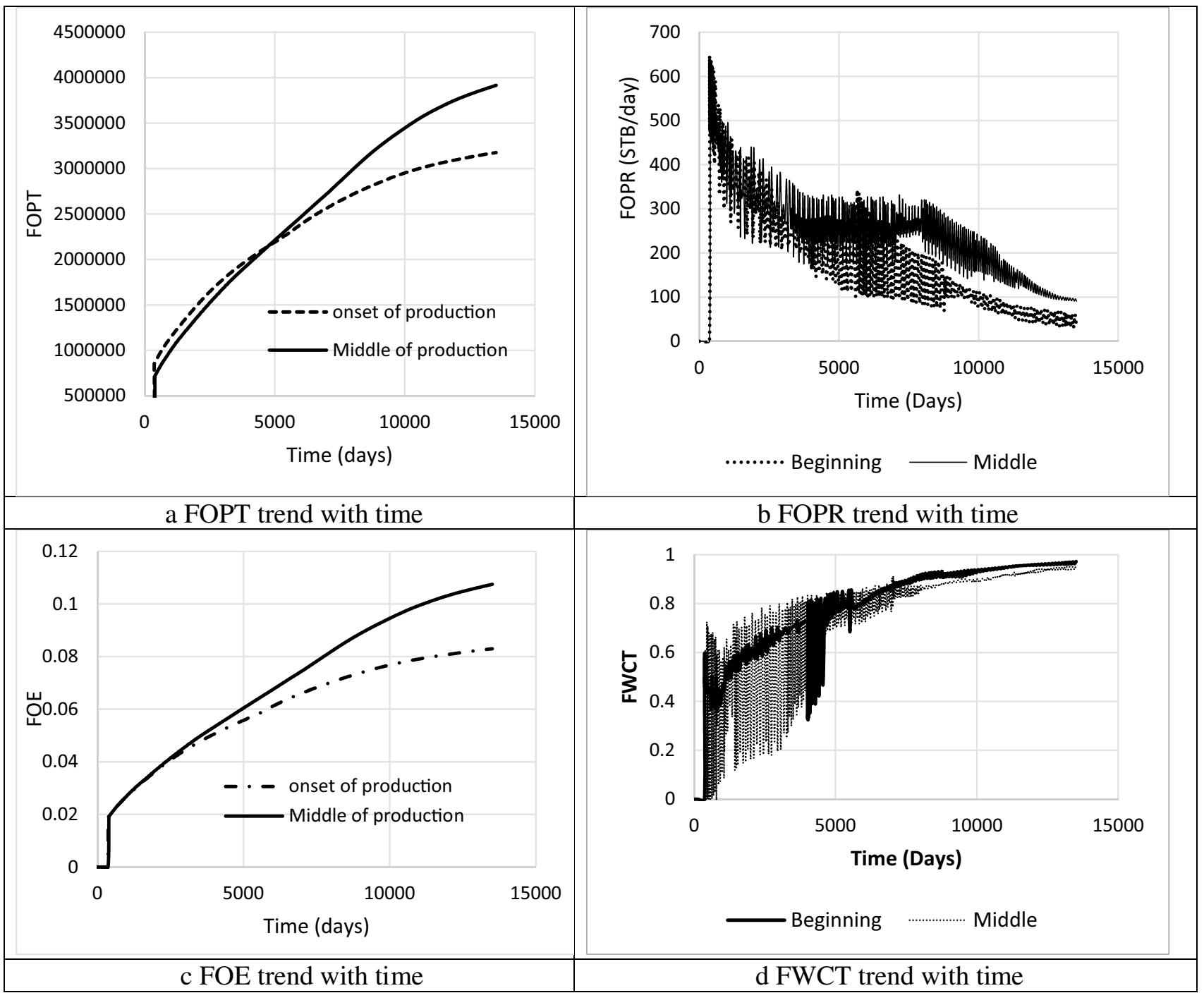

Fig. 12 a FOPT trend with time; b FOPR trend with time; $\mathbf{c}$ FOE trend with time; d FWCT trend with time

Table 6 Results summary for scenario 4

\begin{tabular}{lll}
\hline Results of SAG at November 2046 & \\
\hline & $\begin{array}{l}\text { Beginning of production } \\
\text { (@ 2010) }\end{array}$ & $\begin{array}{l}\text { Middle of } \\
\text { production } \\
\text { (@ 2023) }\end{array}$ \\
\hline FOPT (STB) & $3,175,512$ & $3,915,821$ \\
FOPR (STB/day) & 26.80 & 90.77 \\
FOE & 0.08296 & 0.10749 \\
FWCT & 0.97 & 0.94 \\
\hline
\end{tabular}

Funding No funding was required in the development of this article, but the authors appreciate Covenant University for creating an enabling environment to carry out this research.

Open Access This article is licensed under a Creative Commons Attribution 4.0 International License, which permits use, sharing, adaptation, distribution and reproduction in any medium or format, as long as you give appropriate credit to the original author(s) and the source, provide a link to the Creative Commons licence, and indicate if changes were made. The images or other third party material in this article are included in the article's Creative Commons licence, unless indicated otherwise in a credit line to the material. If material is not included in 
the article's Creative Commons licence and your intended use is not permitted by statutory regulation or exceeds the permitted use, you will need to obtain permission directly from the copyright holder. To view a copy of this licence, visit http://creativecommons.org/licenses/by/4.0/.

\section{References}

Al-Bahar M, Merrill R, Peake W, Jumaa M, Oskui R (2004) Evaluation of IOR potential within Kuwait. Abu Dhabi international conference and exhibition. Socity of Petroleum Engineers, Abu Dhabi

Brashear J, Kuuskraa V (1978) The potential and economics of enhanced oil recovery. J Pet Technol 30:1231-1239

Carcoana A (1982) Enhanced oil recovery in Rumania. SPE enhanced oil recovery symposium. Society of Petroleum Engineers, Tulsa

Chauhan P (2014) Data analysis and summary for surfactant-polymer flooding based on oil field projects and laboratory data. Masters Thesis, Missouri University of Science and Technology. https:// scholarsmine.mst.edu/masters_theses/7323. Accessed 1 Jan 2019

Deishad M, Najafadi NF, Anderson GA, Pope GA, Sepehmoori K (2009) Modelling wettability alteration by surfactants in naturally fractured reservoirs. SPE Reserv Eval Eng 12:361

Dickson J, Leahy-Dios A, Wylie P (2010) Development of improved recovery screening methodologies. SPE improved oil recovery symposium. Society of Petroleum Engineers, Tulsa

Goodlett G, Honarpour M, Chung F, Sarathi P (1986) The role of screening and laboratory flow studies in EOR process evaluation. In: SPE rocky mountain regional meeting. Society of Petroleum Engineers

Hirasaki G, Miller C, Puerto M (2008) Recent advances in surfactant EOR. Soc Pet Eng. https://doi.org/10.2118/115386-MS

Perm Inc (n.d.) Vertical and volumetric sweep efficiencies. Accessed from Perm Inc. TIPM Laboratory. http://www.perminc.com/resou rces/fundamentals-of-fluid-flow-in-porous-media/chapter-4-immis cible-displacement/vertical-volumetric-sweep-efficiencies/

Keshtkar S, Sabeti M, Mohammadi AH (2015) Numerical approach for enhanced oil recovery with surfactant flooding. Ke Ai 99

Maroua J, Mohsen R (2019) Optimization of oil production in an oil rim reservoir using numerical simulation with focus on IOR/EOR application. SPE reservoir characterisation and simulation conference and exhibition. Society of Petroleum Engineers, Abu Dhabi

Nagib M, Ezuka I, Nasr G (2011) Economic comparison of intelligent wells in simultaneous production of oil and gas reserves form a single wellbore. SPE-132925 26:203-210

NPC (1976) Enhanced oil recovery (report). National Petroleum Congress

NPC (1984) Enhanced oil recovery (report). National Petroleum Congress

Olabode O, Egeonu G, Ojo T, Oguntade T (2018a) Predicting the effect of well trajectory and production rates on concurrent oil and gas recovery from thin oil rims. IOP Conf Ser Mater Sci Eng 413:012051
Olabode OA, Egeonu G, Ojo T, Oguntade O, Bamigboye O (2018b) Production forecast for niger delta oil rim synthetic reservoirs. Data Brief 19:2205-2214

Olabode OA, Orodu O, Isehunwa S, Mamudu A, Rotimi T (2018c) Effect of foam and WAG (water alternating gas) injection on performance of thin oil rim reservoirs. J Pet Sci Eng 171:1443-1454

Oluwasanmi O, Orodu O, Sunday I, Daniel A (2020a) Optimizing Productivity in Oil Rims: Simulation Studies on Horizontal Well Placement under Simultaneous Oil and Gas Production. J Pet Explor Prod Technol. https://doi.org/10.1007/s13202-020-01018 $-9$

Olabode O (2020b) Effect of water and gas injection schemes on synthetic oil rim models. J Pet Explor Prod Technol 4:1343-1358

Olabode OA, Ojo T, Oguntade T, Oduwole D, Energy Reports (2020c) Recovery potential of biopolymer (B-P) formulation from Solanum tuberosum (waste) starch for enhancing recovery from oil reservoirs 6. https://doi.org/10.1016/j.egyr.2020.05.027

Olabode O, Alaigba D, Oramabo D, Bamigboye O (2020d) Modelling Low Salinity Water Flooding as a Tertiary Oil Recovery Technique. J Model Simul Eng. https://doi.org/10.1155/2019/6485826

Pope GA (2007) Overview of chemical EOR. Austin, Texas, USA

Robert R, Jacques H (1953) Gas-oil ratio control in thin oil columns. Drilling and Production Practice, New York, API-53-059

Rosen MJ, Kunjappu JT (2012) Surfactants and interfacial phenomena. Wiley, Hoboken

Samsundar K, Moosia R, Chung R (2005) Effective reservoir management of thin oil rims. In: SPE Latin America and Caribbean petroleum engineering conference. Rio De Janeiro: SPE

Sheng JJ (2011) Modern chemical enhanced oil recovery-theory and practice. Gulf Professional Publishing, Houston

Sheng J (2013) Review of surfactant enhanced oil recovery in carbonate reservoirs. Adv Pet Explor Dev 6:1-10

Sheng JJ (2015) Status of surfactant EOR technology. Ke Ai 1:97-105

Sulaiman S, Bretherton T (1989) Thin oil development in the Bream field. In: SPE Asia Pacific conference. Sydney: SPE

Taber J, Martin F, Seright R (1997) EOR screening criteria revisited part 1: introduction to screening criteria and enhanced recovery field projects. SPE Reserv and Eng 12:189-198

University of Bristol (n.d.) What are surfactants. Accessed from University of Bristol. http://www.bristol.ac.uk/chemistry/research/ eastoe/what-are-surfactants/

Vo D, Witjaksana S, Waryan S, Dharmawan A, Harmawan I, Okuno M (2001) Reservoir management for ultrathin oil columns under gas cap and water expansion: Attaka field examples. SPE Asia Pacific oil and gas conference and exhibition (SPE 68675), pp. 1-12, Jakarta

Publisher's Note Springer Nature remains neutral with regard to jurisdictional claims in published maps and institutional affiliations. 